\title{
Pendampingan Materi Sejarah Lokal Masa Revolusi Fisik Bagi Guru Sejarah Sma Se-Kota Lubuklinggau
}

\author{
Muhammad Reza Pahlevi, ${ }^{1}$ Adhitya Rol Asmi, ${ }^{2}$ Syafruddin Yusuf, ${ }^{3}$ \\ Supriyanto, ${ }^{4}$ Alian, ${ }^{5}$ Aulia Novemy Dhita. ${ }^{6}$ \\ 1,2,3,4,5,6, Universitas Sriwijaya \\ ${ }^{1}$ mrpahlevi@fkip.unsri.ac.id, ${ }^{2}$ rolasmi@fkip.unsri.ac.id, ${ }^{3}$ yusufsya@fkip.unsri.ac.id, \\ 4priyan@fkip.unsri.ac.id, 5lialal@fkip.unsri.ac.id, ${ }^{6}$ vodhita@fkip.unsri.ac.id
}

Submitted: 2020-12-08 | Revised: 2021-06-11 | Accepted: 2021-06-11

\begin{abstract}
The community engagement program aims to 1). Introduce information technology for educational purposes, 2). Train teachers in order to apply QR Code application for students' attendance through online with android based, 3) Teachers will able to apply for students' attendance checklist through online. The community engagement program structured conducted which began with a survey and initial assessment as a first step, and followed by delivering program, and monitoring and evaluation steps. The program conducted based on goals and achievement criteria. This community engagement held in the beginning of the semester on 22th February 2020 at SMA Negeri 1 Latambaga, Kolaka regency, Sulawesi Tenggara. There are 25 teachers evolved in this program. The results of this program were improvement of teachers's knowledge on information technology for educational purposes, understanding of teachers to used QR code for online students presence record, and able to apply QR code for QR code as online students presence record with android based.
\end{abstract}

Keywords: Musi Rawas Physical Revolution 1947-1949, local history learning, Lubuklinggau

\begin{abstract}
Abstrak. Kegiatan ini dilaksanakan oleh Tim Pengabdian Prodi Pendidikan Sejarah FKIP Universitas Sriwijaya tahun 2020 dengan menggunakan aplikasi zoom meeting. Adapun urgensi yang melatarbelakangi dilaksanakannya kegiatan ini adalah kurang optimalnya pembelajaran sejarah lokal di SMA yang ada di Musi Rawas dan sekitarnya. Sejarah perjuangan rakyat Musi Rawas pada masa Revolusi Fisik tahun 1947-1949 merupakan salah satu dari sekian banyak sejarah lokal yang terdapat di Provinsi Sumatera Selatan, tepatnya di Kabupaten Musi Rawas. Selama ini para guru hanya berfokus pada materi sejarah nasional yang terdapat di dalam buku teks pemerintah. Padahal, materi yang ada di dalam buku-buku teks pemerintah jauh dari realitas dan keadaan yang ada di sekitar peserta didik. Metode yang digunakan dalam kegiatan ini adalah metode ceramah yang divariasikan dengan diskusi dan tanya-jawab, serta penugasan dan demonstrasi yang dilakukan oleh peserta. Kegiatan ini dapat dikatakan
\end{abstract}


berhasil dilaksanakan dengan indikator terjadinya peningkatan pemahaman para guru mengenai sejarah perjuangan rakyat Musi Rawas pada masa Revolusi Fisik tahun 19471949 dengan skor rata-rata pre-test sebesar 44,67 dan skor rata-rata post-test sebesar 94. Angka tersebut menunjukkan selisih sebesar 49,33 yang berarti terdapat peningkatan pemahaman terhadap sejarah lokal perjuangan rakyat Musi Rawas pada masa Revolusi Fisik 1947-1949 setelah dilakukannya kegiatan pengabdian pada masyarakat dalam bentuk pendampingan materi sejarah lokal.

Kata Kunci: Revolusi Fisik Musi Rawas 1947-1949, pembelajaran sejarah lokal, Lubuklinggau

\section{Pendahuluan}

Sejarah merupakan salah satu cabang ilmu yang meneliti dan menyelidiki secara sistematis keseluruhan perkembangan masyarakat, kejadian masa lampau, dan menilai secara kritis hasil dari penelitian tersebut ${ }^{1}$. Sementara itu, pembelajaran sejarah sering diidentikkan dengan kegiatan menghafal tanggal, tahun, tokoh, dan rentetan peristiwa masa lalu' ${ }^{2}$. Namun demikian pembelajaran sejarah sejatinya tidak sampai di titik tersebut. Kondisi ideal dari pembelajaran sejarah yang diharapkan yaitu peserta didik dapat mengekstrapolasikan faktafakta yang berperan di masa lampau dan membuat proyeksi masa depan sehingga mereka mengetahui kebermanfaatan dari belajar sejarah. Pembelajaran sejarah di Indonesia sendiri mulai diajarkan dari tingkat sekolah menengah hingga perguruan tinggi.

Menurut Kochar, pembelajaran sejarah di jenjang Sekolah Menengah Atas (SMA) harus didasarkan pada beberapa hal, yaitu: (1) pengetahuan dan pemahaman pada istilah, konsep, fakta, dan peristiwa; (2) pemikiran kritis atau mengembangkan pemikiran kritis; (3) mengembangkan keterampilan praktis peserta didik dalam memahami fakta sejarah; (4) mengembangkan minat dalam belajar sejarah dan; (5) mengembangkan perilaku sosial yang sehat ${ }^{3}$. Berdasarkan hal di atas, maka dapat disimpulkan bahwa pembelajaran sejarah pada jenjang SMA tidak hanya sekedar pada ranah menghafalkan sejumlah peristiwa, tahun, tanggal dan tokohnya semata, namun dapat mengembangkan pemikiran kritis dan pembentukan sikap sosial peserta didik sehingga siap terjun pada lingkungan masyarakat secara nyata.

Kurikulum 2013 sebagai kurikulum terbaru yang diterapkan dalam pendidikan di Indonesia mempunyai beberapa prinsip, yaitu: Pertama, pembelajaran berpusat pada peserta didik dan memberikan kesempatan untuk mengasimilasi dan mengakomodasi konsep. Kedua, memberikan kesempatan untuk melatih kemampuan dalam komunikasi dan merekonstruksi pemikirannya

\footnotetext{
1 Said Hamid Hasan, Pendidikan Sejarah, Kemana dan Bagaimana? Makalah dipresentasikan di Seminar Asosiasi Guru Sejarah, (Jakarta: 2015), h. 7.

2 Abd. Rahman Hamid, Pembelajaran Sejarah, (Yogyakarta: Ombak, 2014), h. 9.

${ }^{3}$ S. K. Kochar, Teaching of History, (Jakarta: Gramedia Widiasarana, 2008), h. 51-53.
} 
sendiri. Dalam pelaksanaannya, Kurikulum 2013 telah merekomendasikan pendekatan saintifik sebagai model pembelajaran efektif. Pendekatan ini mempunyai beberapa kriteria di antaranya: (1) Materi pembelajaran berbasis fakta dan fenomena yang dapat dikaji dengan menggunakan berbagai sumber; (2) Mendorong peserta didik untuk berfikir secara kritis, analistis, dan tepat dalam mengidentifikasi, memahami, dan mengaplikasikan materi pembelajaran dengan menggunakan pendekatan ilmiah; (3) Mengembangkan pola berfikir rasional dan objektif dalam merespon pembelajaran, dan; 4) Mendukung dan memfasilitasi pada penguasaan keterampilan aplikatif ${ }^{4}$. Berdasarkan pada Kurikulum 2013 dan pendekatan saintifik di atas, maka dapat disimpulkan bahwa implementasi pembelajaran sejarah harus memperhatikan beberapa hal, yaitu; Pertama, pembelajaran sejarah harus mampu mengintegrasikan pembelajarannya dengan kehidupan nyata. Kedua, pembelajaran sejarah harus mengembangkan indikator pembelajaran dengan memperhatikan relevansinya terhadap perkembangan dan kebutuhan peserta didik. Ketiga, menyediakan sarana dan prasarana yang memadai. Keempat, melakukan penilaian secara berkala dan berkelanjutan. Dalam hal ini, poin kesatu dan kedua dapat difasilitasi dengan pembelajaran sejarah lokal yang dapat dipelajari oleh peserta didik di sekolah-sekolah.

Menurut Sartono Kartodirdjo ${ }^{5}$ (dalam Sayono ${ }^{6}$ ), pembelajaran sejarah harus menggunakan pendekatan lokosentris, yakni pembelajaran sejarah dengan berpijak pada sejarah lokal. Guru harus memahami prinsip paralelisme waktu dalam menyajikan suatu peristiwa dengan peristiwa di tingkat lokal. Artinya, peristiwa nasional harus dikaitkan dengan peristiwa lokal tempat mereka bertugas. Mengenai skup spasial atau ruang lingkup dari sejarah lokal itu sendiri, Abdullah $^{7}$ memberikan batasan sejarah lokal sebagai sejarah dari suatu "tempat", suatu "locality", yang batasannya ditentukan oleh "perjanjian" yang diajukan oleh sejarawan atau penulisnya. Pembelajaran sejarah lokal sangat penting bagi peserta didik karena berkenaan langsung dengan kenyataan yang berada di sekitarnya. Hal ini dipertegas oleh pendapat Wineburg ${ }^{8}$ dalam tulisannya yang berjudul "Making Historical Sense" sebagai berikut:

Each of us grows up in a home with a distinct history and a distinct perspective on the meaning of larger historical events. Our parents' histories shape our historical consciousness, as do the stories of the ethnic, racial, and religious groups that number

${ }^{4}$ Zia Ulhaq, Tuti Nuriah, Winarsih, dan Murni, Pembelajaran Sejarah Berbasis Kurikulum 2013 di SMA Kotamadya Jakarta Timur, (Jurnal Pendidikan Sejarah 6 (2), 2017), h. 8.

${ }^{5}$ Sartono Kartodirdjo, Pendekatan Ilmu Sosial dalam Metodologi Sejarah. Jakarta: Gramedia Pustaka Utama, 1992).

${ }^{6}$ Joko Sayono, Pembelajaran Sejarah di Sekolah: Dari Pragmatis Ke Idealis, (Jurnal Sejarah Dan Budaya 7 (1), 2013), h. 14.

7 Taufik Abdullah, Di Sekitar Sejarah Lokal di Indonesia. Dalam Taufik, Abdullah (ed). Sejarah Lokal di Indonesia, (Yogyakarta: Gadjah Mada University Press, 1985), h. 15.

${ }^{8}$ Sam Wineburg, Making Historical Sense In Knowing, Teacbing, and Learning History: National and International Perspectives, edited by Peter N. Stearns, Peter Seixas and Sam Wineburg 306-25, (New York: University Press, 2000), h. 310. 
us as a member. We attend churches, clubs, and neighborhood associations that further mold both our collective and our individual historical sense.

Jika dilihat dari pendapat di atas, maka pembelajaran sejarah lokal sangat penting untuk mengembangkan jati diri pribadi, budaya dan sosial peserta didik. Pembelajaran sejarah konvensional yang hanya memberikan penekanan terhadap sejarah orang-orang besar (great man) dan terpusat pada pembelajaran sejarah nasional maupun internasional, akan terasa kering karena jauh dari realitas yang ada di sekitar peserta didik. Padahal, sejarah lokal dapat memberikan landasan nasionalisme kepada peserta didik sebelum mereka memahami peristiwa yang lebih besar di tingkat nasional. Berkaitan dengan hal tersebut, Hariyono9 dan Zahro, et al $^{10}$ mengatakan bahwa untuk menjaga dimensi keindonesiaan di masa depan, dimana wilayah dan kebudayaan Indonesia yang beragam, maka diperlukan penjelasan dan pemahaman yang lebih detail sekaligus beragam sebagai bahan rajutan kebhinekaan. Oleh karena itu, sejarah lokal memiliki arti dan fungsi yang strategis dalam upaya pembentukan karakter bangsa sekaligus menanamkan nilai budaya. Untuk mengupayakan hal tersebut sekaligus memperkuat pemahaman mengenai sejarah lokal, maka diperlukan kompetensi dan literasi yang baik dari pendidik maupun peserta didik yang mengkajinya.

Tujuan dari pembelajaran literasi sejarah lokal sendiri menurut Widja ${ }^{11}$ adalah untuk mendorong peserta didik dalam proses pemberdayaan diri dan penanaman kesadaran sosial. Sejarah lokal dapat dikatakan sebagai bentuk penulisan dari sejarah dalam lingkup yang terbatas dan meliputi lokalitas tertentu. Lingkup yang dimaksud adalah penulisan sejarah lokal yang dikaitkan dengan unsur suatu wilayah. Penulisan sejarah lokal menjadi penting, mengingat ruang lingkup yang sempit akan lebih mengenalkan masyarakat dari bagian yang kecil. Untuk mengetahui kesatuan yang lebih besar, maka bagian yang lebih kecil harus dimengerti dengan baik. Pendapat tersebut juga didukung oleh Levesque ${ }^{12}$ yang mengatakan bahwa pembelajaran literasi sejarah dapat dimulai dengan mempelajari peristiwa lokalitas yang berada di lingkungan peserta didik. Jenis sejarah ini merupakan unit sejarah yang mempunyai ciri khas sebagai kesatuan etnis dan kultural satu dimensi dari Sejarah Nasional Indonesia. Mengingat hal tersebut, maka sejarah lokal seharusnya menjadi bagian penting dalam silabus sejarah pada semua jenjang pendidikan. Pertimbangan ini didasarkan pada rasa

${ }^{9}$ Hariyono, Sejarah Lokal: Mengenal yang Dekat, Memperluas Wawasan, (Sejarah dan Budaya : Jurnal Sejarah, Budaya, dan Pengajarannya, 11 (2), 2017), h. 161.

10 Zahro, M., Sumardi, \& Marjono, The Implementation Of The Character Education In History Teaching, (Jurnal Historica, 1 (2252), 2017), h. 2-3.

${ }^{11}$ I Gde Widja, Sejarah Lokal Suatu Perspektif dalam Pengajaran Sejarah. (Jakarta: Departemen Pendidikan dan Kebudayaan, 1989), h. 13-14.

${ }^{12}$ Levesque, S, On Historical Literacy: Learning to Think Like Historian, Journal for Social Research 3 (2), 2010), h. 42. 
ketertarikan yang dapat merangsang imajinasi peserta didik pada sejarah serta memperkenalkan teknik penelitian sejarah yang paling dasar.

Berdasarkan observasi yang dilakukan oleh tim pengabdian Prodi Pendidikan Sejarah FKIP Universitas Sriwijaya (UNSRI), pembelajaran sejarah lokal di sekolah-sekolah di Lubuklinggau masih belum optimal untuk dilakukan. Hal ini dibuktikan dengan masih rendahnya pemahaman guru dan siswa dalam menelaah sejarah lokal yang terdapat di sekitarnya. Selama ini para guru seringkali berfokus dalam pengajaran sejarah nasional yang terdapat di dalam buku teks pemerintah. Hal inilah yang membuat pembelajaran sejarah dirasa kurang bermakna karena tidak mampu memfasilitasi peserta didik dengan pengalaman nyata sekitarnya dan jauh dari realitas peserta didik sehari-hari. Padahal, semenjak berakhirnya era Orde Baru, melalui Undang-Undang No. 22/1999 tentang Otonomi Daerah, daerah diberikan kewenangan dalam menyusun kurikulum pendidikan, termasuk materi sejarahnya tersendiri. Hal ini berarti membuka peluang bagi para guru untuk dapat mengembangkan materi sejarah lokal disamping pengajaran materi sejarah nasional. Pada titik ini, guru sejatinya dapat mengembangkan bahan ajarnya sendiri yang kemudian dapat disisipkan materi sejarah lokal yang ada disekitarnya. Bahan ajar yang baik harus dikembangkan berdasarkan kebutuhan peserta didik dan kurikulum yang digunakan. Hal ini dikarenakan setiap peserta didik dan sekolah mempunyai kondisi dan kemampuan yang berbeda-beda. Terkait bahan ajar yang baik, Zuchdi (dalam Akbar ${ }^{13}$ ) menyatakan terdapat beberapa hal yang harus diperhatikan, yaitu, (1) bahan ajar harus dikembangkan memperhatikan tingkat akurasi dalam hal kecermatan penyajian dan kebenaran sumber (2) relevansi, memperhatikan kesesuaian antara kompetensi yang harus dicapai dengan cangkupan isi, kedalaman pembahasan dan kompetensi membaca, (3) komunikatif, isi buku mudah dicerna, sistematis, jelas, dan tidak mengandung kesalahan Bahasa, dan (4) berorientasi pada student-centered, merangsang peserta didik untuk membangun pengetahuan sendiri. Selain itu, Komalasari ${ }^{14}$ berpendapat bahwa bahan ajar diharuskan mencakup beberapa hal penting seperti kegiatan refleksi diri, proses explorasi, ekspresi kreatif, keterampilan personal, sosial, emosional, dan penilaian sikap. Selain itu, penyajian buku teks diharuskan bersifat sistematis, koheren, konsisten, dan memenuhi tuntutan kurikulum 2013.

Hasil observasi dan diskusi dengan guru-guru mata pelajaran sejarah yang tergabung dalam Musyawarah Guru Mata Pelajaran (MGMP) Sejarah Lubuklinggau, diketahui bahwa di dalam materi sejarah lokal Kurikulum 2013 yang terdapat dalam buku teks mata pelajaran sejarah peminatan Ilmu-Ilmu Sosial Kelas XII Semester I edisi revisi, dengan materi Respon internasional

\footnotetext{
13 Akbar, S, Instrumen Perangkat Pembelajaran, (Bandung: PT Remaja Rosdakarya, 2013), h. 34-35.

${ }^{14}$ Kokom Komalasari, The Influence of Living V alues Education-Based Civic Education Textbook on Students' Character Formation, (International Journal of Instruction 11 (1), 2018), h. 400-401.
} 
terbadap Proklamasi Kemerdekaan Indonesia, sub bab Respon Belanda terhadap Proklamasi Kemerdekaan Indonesia dan Perlawanan Bangsa Indonesia terbadap kembalinya Belanda, hanya menjelaskan materi tentang perlawanan rakyat Palembang terhadap Belanda dalam Perang Lima Hari Lima Malam yang terjadi di Kota Palembang. Namun demikian, sebenarnya peristiwa tersebut tidak berhenti di Kota Palembang, namun meluas hingga ke daerah uluan atau pedalaman yang berujung pada terbentuknya pusat pertahanan yang disebut Sub Komandemen Sumatera Selatan (Subkoss) yang berpusat di Musi Rawas pada masa itu ${ }^{15}$. Hal tersebut perlu untuk diketahui oleh peserta didik, bahwa daerah Musi Rawas (Lubuklinggau dan sekitarnya) mempunyai peranan yang sangat penting dalam masa-masa perjuangan mempertahankan kemerdekaan Republik Indonesia. Pentingnya pembelajaran sejarah lokal menjadi sebuah keharusan agar peserta didik mengenal lebih dekat realitas yang terjadi disekitarnya. Untuk itu, pembelajaran sejarah lokal harus diperkuat dengan terlebih dahulu memberikan pemahaman terhadap sejarah lokal kepada para guru.

Pada dasarnya, kegiatan pengabdian yang dilakukan terhadap guru-guru sejarah adalah wujud kekhawatiran terhadap belum optimalnya profesionalitas dan kompetensi guru-guru di sekolah. Di bawah ini, setidaknya ada lima kegiatan pengabdian yang pernah dilakukan dengan sasaran dan tema serupa dengan kegiatan yang dilakukan. Kegiatan pengabdian yang pertama dilakukan oleh Suryadi" ${ }^{16}$, dengan mengangkat tema "Meningkatkan kompetensi pedagogik guru-guru sejarah SMA di Kota Semarang dalam kemampuan pemanfaatan media melalui pelatihan aplikasi teknologi google earth dalam pembelajaran sejarah". Kegiatan ini berhasil dilakukan dengan indikator bahwa peserta pengabdian sudah mulai mengenal, mampu memanfaatkan, dan merasakan nilai lebih dari penggunaan teknologi google earth dalam pembelajaran sejarah. Selain itu, Saripudin et $\mathrm{al}^{17}$, juga pernah melakukan kegiatan pengabdian dengan tema "Pelatihan pembuatan dan pemanfaatan replika sejarah dan peta E-Pen bagi guru-guru sejarah SMA/MA". Kegiatan ini didasarkan atas urgensi bahwa masih banyak guru sejarah di Kabupaten Sukabumi yang belum dapat memanfaatkan media pembelajaran secara optimal. Hasil dari kegiatan ini menunjukkan bahwa pengembangan media pembelajaran sejarah berupa replika dan peta e-pen yang dilakukan oleh guru-guru sejarah SMA/MA merupakan saran efektif dalam membantu guru untuk membentuk kreativitasnya membuat media replika dan e-pen. Selain dua kegiatan di atas, ada juga pengabdian yang

\footnotetext{
15 Syafruddin Yusuf, Adhitya Rol Asmi, dan Muhammad Reza Pahlevi, Perjuangan Rakyat Musi Rawas pada masa Revolusi Fisik 1947-1949, (Palembang: Program Studi Pendidikan Sejarah FKIP Universitas Sriwijaya, 2020), h. 41.

16 Suryadi, A, Guru-Guru Sejarah SMA di Kota Semarang dalam Kemampuan Pemanfaatan Media Google Earth dalam Pembelajaran. (Jurnal Penerapan Teknologi dan Pembelajaran, 11 (2), 2013) h. 95-104.

${ }^{17}$ Didin Saripudin, Leli Yulifar, dan Anggraini, D. N, Pelatihan Pembuatan dan Pemanfaatan Replika Sejarab dan Peta E-Pen Bagi Guru-Guru SMA/MA. (ABDI: Jurnal Pengabdian dan Pemberdayaan Masyarakat, 3 (1) Juni, 2021).
} 
dilakukan Marta" dengan bertema "Penelitian Tindakan Kelas sebagai upaya peningkatan profesionalisme guru sejarah di Sekolah Menengah Atas Kabupaten Bogor. Kegiatan ini berhasil dilakukan dengan indikator bahwa sebanyak 50\% peserta pengabdian mampu menemukan masalah yang dapat diangkat dalam Penelitian Tindakan Kelas dan merumuskan masalah serta hipotesis penelitian. Selain itu, ada juga pengabdian yang dilakukan oleh Pahlevi dan Hudaidah" dengan tema "Penyuluhan dan pelatihan pembuatan laporan Penelitian Tindakan Kelas bagi guru sejarah Sekolah Menengah Atas di Palembang. Kegiatan ini berhasil dilakukan dengan indikator peserta pengabdian mampu membuat laporan Penelitian Tindakan Kelas setelah kegiatan dilaksanakan. Kegiatan pengabdian dengan tema serupa di tulisan ini juga pernah dilakukan oleh Wiyanarti et $\mathrm{al}^{20}$ dengan tema Pengembangan Sejarah Lokal sebagai Sumber Pembelajaran Sejarah yang Kontekstual. Sasaran pengabdiannya adalah guru-guru sejarah yang tergabung dalam MGMP Sejarah di Kabupaten Tasikmalaya, Jawa Barat. Hasil dari pengabdian tersebut adalah peserta pengabdian sudah mampu, setidaknya secara simulatif, dalam menggali potensi untuk mengembangkan sejarah lokal sebagai sumber pembelajaran sejarah.

Seperti yang telah dikemukakan sebelumnya, kegiatan-kegiatan di atas dilakukan dalam upaya untuk meningkatkan profesionalitas dan kompetensi guru-guru sejarah. Namun demikian kegiatan pengabdian yang menyoroti pada dimensi penguatan sejarah lokal belum banyak dilakukan. Padahal, guru sejarah adalah fasilitator pertama di sekolah-sekolah untuk mengenalkan peristiwa lokal sekaligus mengenalkan konsepsi sejarah lokal kepada peserta didik. Hal inilah yang membuat Prodi Pendidikan Sejarah FKIP Universitas Sriwijaya berinisiatif untuk memberikan pendampingan materi sejarah lokal terhadap guru-guru sejarah yang ada di daerah Musi Rawas dan sekitarnya.

Peserta dalam pendampingan ini adalah guru-guru sejarah yang tergabung dalam MGMP Lubuklinggau dan beberapa guru dan dosen yang berada di sekitar wilayah Musi Rawas. Kegiatan ini dilaksanakan secara daring, melalui aplikasi zoom meeting mengingat adanya pembatasan sosial terkait pandemi Covid 19 yang sedang terjadi. Pendampingan materi sejarah lokal ini sendiri dilaksanakan dengan dua tahapan, yaitu Pelatihan Terbimbing dan Pelatihan Mandiri. Pada tahapan Pelatihan Terbimbing, para narasumber akan memaparkan materi-materi yang berkenaan dengan sejarah lokal untuk memperkaya pengetahuan peserta pengabdian terkait aspek teoretik sampai

\footnotetext{
18 Marta, N, Penelitian Tindakan Kelas sebagai Upaya Peningkatan Profesionalisme Guru Sejarah di Sekolah Menengah Atas Kabupaten Bogor. (17(1)), h. 22-29.

19 Muhammad Reza Pahlevi dan Hudaidah, Penelitian Tindakan Kelas Bagi Guru Sejarah Sekolah Menengah Atas di Palembang. (Jurnal Praksis dan Dedikasi Universitas Negeri Malang, 3(1), 2020), h. 34-38.

${ }^{20}$ Erlina Wiyanarti, Nana Supriatna, dan Winarti, M, Pengembangan Sejarah Lokal Sebagai Sumber Pembelajaran Sejarah Yang Kontekstual. (FACTUM: Jurnal Sejarah dan Pendidikan Sejarah, 9 (1), 2020), h. 67-74.
} 
kepada pengembangan bahan ajar sejarah lokal yang baik. Metode yang digunakan pada tahap Pelatihan Terbimbing ini adalah metode ceramah yang divariasikan dengan diskusi dan tanya-jawab. Adapun teknik penyampaian materi menggunakan slide power point dan media podcast yang berisikan materi pendampingan. Sementara itu, Pelatihan Mandiri dilaksanakan melalui metode penugasan dan demonstrasi. Pada tahapan ini, peserta diminta untuk membuat produk bahan ajar sejarah lokal sebagai output kegiatan yang dilakukan.

\section{Hasil dan Pembahasan}

\section{Kronologis Kegiatan}

Kegiatan ini dilaksanakan selama empat hari yang dimulai dari Hari Sabtu, 14 November 2020 sampai Hari Selasa, 17 November 2020. Peserta pendampingan materi sejarah lokal masa Revolusi Fisik ini berjumlah 3o orang yang berasal dari 24 sekolah yang ada di Sumatera Selatan. Rincian peserta pengabdian dapat dilihat melalui tebel di bawah ini.

Tabel 1. Nama Peserta, Asal Sekolah, dan Asal Daerah

\begin{tabular}{|c|l|l|c|}
\hline NO & \multicolumn{1}{|c|}{ NAMA } & \multicolumn{1}{|c|}{ ASAL SEKOLAH } & ASAL DAERAH \\
\hline $\mathbf{1}$ & $\begin{array}{l}\text { Agus Sumadiy Muntako } \\
\text { S.Pd. }\end{array}$ & SMA Negeri 1 Lubuklinggau & Musi Rawas \\
\hline $\mathbf{2}$ & Agnes Maria Comba, S.Pd. & SMA Negeri 1 Lubuklinggau & Musi Rawas \\
\hline $\mathbf{3}$ & Dina Hardyaningrum, S.Pd & SMA Negeri 3 Lubuklinggau & Musi Rawas \\
\hline $\mathbf{4}$ & Carlos Dody, S.Pd. & SMA Negeri 3 Lubuklinggau & Musi Rawas \\
\hline $\mathbf{5}$ & Anita, S.Pd. & SMA Negeri 3 Lubuklinggau & Musi Rawas \\
\hline $\mathbf{6}$ & Sunyoto, S.Pd. & SMA Negeri 4 Lubuklinggau & Musi Rawas \\
\hline $\mathbf{7}$ & $\begin{array}{l}\text { Sisca Arie Hanika, S.Pd., } \\
\text { M.M. }\end{array}$ & SMA Negeri 5 Lubuklinggau & Musi Rawas \\
\hline $\mathbf{8}$ & Khotmil Ikhsan, S.Pd & SMA Negeri 5 Lubuklinggau & Musi Rawas \\
\hline $\mathbf{9}$ & Anton Ratip Dwi, S.Pd. & SMA Negeri 5 Lubuklinggau & Musi Rawas \\
\hline $\mathbf{1 0}$ & Sunardi, M.Pd & SMA Negeri 6 Lubuklinggau & Musi Rawas \\
\hline $\mathbf{1 1}$ & Yusnan halomoan, S.Pd. & SMA Negeri 7 Lubuklinggau & Musi Rawas \\
\hline $\mathbf{1 2}$ & Endang Partiyem, M.Pd. & SMA Negeri 9 Lubuklinggau & Musi Rawas \\
\hline $\mathbf{1 3}$ & Endah May Sutanti, S.Pd & SMA Yadika Lubuklinggau & Musi Rawas \\
\hline $\mathbf{1 4}$ & Muhammad Yusuf, S.Pd. & SMAN Surulangun & Musi Rawas \\
\hline $\mathbf{1 5}$ & Desy Pratiwi, S.Pd. & SMA Negeri Muara Kelingi & Musi Rawas \\
\hline $\mathbf{1 6}$ & Elsa Tryana, S.Pd. & SMA Negeri Bangun Jaya & Musi Rawas \\
\hline $\mathbf{1 7}$ & Saiful Amri, S.Pd., M.Hum. & SMA Negeri Selangit & Musi Rawas \\
\hline $\mathbf{1 8}$ & $\begin{array}{l}\text { Muhammad Bahrudin, } \\
\text { S.Pd }\end{array}$ & SMAN 2 Muara Beliti & Musi Rawas \\
\hline $\mathbf{1 9}$ & Agus Rosady, S.Pd., M.Pd. & SMAN Marga Baru & Musi Rawas \\
\hline $\mathbf{2 0}$ & Nazula Erli, S.Pd. & SMAN Tugumulyo & Musi Rawas \\
\hline $\mathbf{2 1}$ & Rohima, S.Pd. & SMAN Megang sakti & Musi Rawas \\
\hline $\mathbf{2 2}$ & Neni Triani, S.Pd. & SMA Negeri 1 Kikim Timur & Lahat \\
\hline
\end{tabular}




\begin{tabular}{|c|l|l|c|}
\hline $\mathbf{2 3}$ & Nurleni Kartika Sari, S.Pd. & MA Negeri 2 Palembang & Palembang \\
\hline $\mathbf{2 4}$ & Ratih Purnama Sari, S.Pd. & $\begin{array}{l}\text { SMP Negeri 3 Semendawai } \\
\text { Suku III }\end{array}$ & OKU Timur \\
\hline $\mathbf{2 5}$ & Riswati, S.Pd. & SMK Negeri 1 Sekayu & Musi Banyuasin \\
\hline $\mathbf{2 6}$ & $\begin{array}{l}\text { Sandra Ryan Prabowo, } \\
\text { S.Pd. }\end{array}$ & SMA Srijaya Negara & Palembang \\
\hline $\mathbf{2 7}$ & Dwi Yolanda Sari, S.Pd. & SMA Negeri 1 Sekayu & Musi Banyuasin \\
\hline $\mathbf{2 8}$ & $\begin{array}{l}\text { Nurmutmainah, S.Pd., } \\
\text { M.Si. }\end{array}$ & SMA Negeri 5 Palembang & Palembang \\
\hline $\mathbf{2 9}$ & Yosi Susanti, S.Pd., M.Si. & SMA Negeri 20 Palembang & Palembang \\
\hline $\mathbf{3 0}$ & Efdi Wahyudi, S.Pd. & SMP Negeri 2 Tanah Abang & Palembang \\
\hline
\end{tabular}

Kegiatan pengabdian ini berjalan lancar hingga akhir acara karena partisipasi para guru yang antusias dalam menerima materi dan diskusi. Pada awal kegiatan, para peserta melakukan registrasi dan masuk ke dalam ruang room meeting yang telah disediakan. Kegiatan diawali dengan melaksanakan pre test untuk mengetahui pengetahuan awal peserta pengabdian mengenai materi pendampingan. Tingkat pengetahuan awal yang dimiliki oleh peserta pengabdian diketahui dari data nilai pre-test yang diberikan kepada peserta di awal kegiatan. Pre-test ini terdiri dari sepuluh soal pilihan ganda mengenai sejarah lokal di Musi Rawas. Adapun hasil pre test dapat dilihat melalui tabel berikut:

Tabel 2. Hasil Pre Tes Pengetahuan Awal Peserta Didik

\begin{tabular}{c|c|c|c|c|c|}
\hline Tes & N & Skor & Rata-Rata & $\begin{array}{c}\text { N } \\
\text { Min }\end{array}$ & $\begin{array}{c}\text { N } \\
\text { Max }\end{array}$ \\
\hline Awal (Pre) & 30 & 1340 & 44,67 & 20 & 100 \\
\hline
\end{tabular}

Berdasarkan data di atas, dapat dilihat bahwa nilai rata-rata pre test peserta pendampingan masih tergolong rendah, yaitu sebesar 44,67 dengan nilai paling rendah berada pada angka 20 dan nilai tertinggi berada pada angka 100 . Data tersebut menjadi dasar pertimbangan tim pengabdian untuk melakukan kegiatan pendampingan guna mencapai tujuan kegiatan. Kegiatan selanjutnya adalah pembukaan kegiatan yang disampaikan oleh Koordinator Program Studi Pendidikan Sejarah FKIP UNSRI, Dr. Syarifuddin, M.Pd dan Ketua Tim Pengabdian Prodi Pendidikan Sejarah FKIP UNSRI, Adhitya Rol Asmi, M.Pd. Setelah doa, kegiatan dilanjutkan dengan penyampaian materi oleh narasumber pada hari pertama yang disampaikan oleh Drs. Alian, M.Hum., Drs. Supriyanto, M.Hum, dan Adhitya Rol Asmi, M.Pd. Hari kedua, Minggu tanggal 15 November 2020 kegiatan pengabdian dilanjutkan dengan pendampingan materi yang disampaikan oleh 3 narasumber yang terdiri dari Aulia Novemy Dhita, M.Pd, Drs. Syafruddin Yusuf, M.Pd., Ph.D, dan Muhammad Reza Pahlevi, M.Pd. Kegiatan Pelatihan Mandiri dalam bentuk penugasan dilakukan pada hari ketiga, dan pada hari keempat atau hari terakhir, peserta pengabdian 
mengumpulkan tugas sekaligus melakukan demonstrasi materi ajar. Kegiatan ditutup dengan melakukan post tes dan evaluasi terhadap produk yang telah dibuat oleh masing-masing peserta pengabdian.

\section{Pelaksanaan Pelatihan Terbimbing}

Kegiatan Pelatihan Terbimbing dilaksanakan pada Hari Sabtu dan Minggu, tanggal 14-15 November 2020. Narasumber pada hari pertama adalah Drs. Alian, M.Hum, Drs. Supriyanto, M.Hum, dan Adhitya Rol Asmi, M.Pd. Semua narasumber pada hari pertama ini menjelaskan mengenai dasar-dasar sejarah lokal. Narasumber pertama, Drs. Alian, M.Hum menjelaskan mengenai "Metodologi dan Pengembangan Sejarah Lokal dalam Buku Teks" yang disampaikan melalui metode ceramah dengan waktu paparan selama kurang lebih 50 menit. Selanjutnya, materi kedua disampaikan oleh Drs. Supriyanto, M.Hum dengan materi mengenai "Sejarah Lokal" dengan waktu paparan materi selama 50 menit. Materi ketiga sekaligus materi terakhir di hari pertama disampaikan oleh Adhitya Rol Asmi, M.Pd dengan materi "Pengemasan Materi Sejarah dalam Buku Ajar" yang dipaparkan selama 30 menit.

Pada hari kedua, Minggu tanggal 15 November 2020, kegiatan pengabdian dilanjutkan dengan pendampingan materi yang disampaikan oleh 3 narasumber yang terdiri dari Aulia Novemy Dhita, M.Pd, Drs. Syafruddin Yusuf, M.Pd., Ph.D, dan Muhammad Reza Pahlevi, M.Pd. Materi pertama di hari kedua dipaparkan oleh Aulia Novemy Dhita Surbhakti, M.Pd dengan materi mengenai "Penerapan Podcast dalam Pembelajaran Sejarah" yang disampaikan dengan waktu selama 30 menit. Materi kedua sekaligus materi inti dari pendampingan materi di kegiatan ini disampaikan oleh Drs. Syafruddin Yusuf, M.Pd., Ph.D yang membahas mengenai "Perjuangan rakyat Musi Rawas pada masa Revolusi Fisik 1947-1949" sekaligus membedah buku hasil penelitian dengan tema tersebut. Materi terakhir pada hari kedua disampaikan oleh Muhammad Reza Pahlevi, M.Pd dengan materi mengenai "Pembelajaran Sejarah yang Bermakna" yang dipaparkan selama 30 menit.

\section{Pelaksanaan Pelatihan Mandiri}

Pada kegiatan Pelatihan Mandiri, peserta difokuskan untuk mengemas materi inti yang sudah disampaikan oleh Drs. Syafruddin Yusuf, M.Pd., Ph.D pada hari sebelumnya. Kegiatan pengemasan materi ini dilakukan dalam bentuk penugasan yang dilaksanakan pada hari ketiga, Senin 16 November 2020. Sementara itu, pada hari keempat atau hari terakhir kegiatan, peserta diminta untuk mengumpulkan tugas dan melakukan demonstrasi berupa materi sejarah lokal masa Revolusi Fisik dalam bentuk media pembelajaran podcast.

Pelaksanaan kegiatan pengabdian ini diakhiri dengan kegiatan evaluasi guna melihat pemahaman akhir peserta pengabdian sekaligus mengukur ketercapaian pelaksanaan kegiatan. Evaluasi dilakukan dengan melaksanakan post tes pengetahuan terhadap materi yang sudah diberikan dan penilaian produk 
yang dibuat oleh peserta pengabdian melalui Pelatihan Mandiri. Di bawah ini merupakan tabel perbandingan hasil pre-test dan post-test yang didapatkan setelah penghitungan.

Tabel 3. Rekapitulasi Hasil Tes Pengetahuan

\begin{tabular}{c|ccccc|}
\hline Tes & N & Skor & Rata-Rata & $\begin{array}{c}\text { N } \\
\text { Min }\end{array}$ & $\begin{array}{c}\text { N } \\
\text { Max }\end{array}$ \\
\hline Awal (Pre) & 30 & 1340 & 44,67 & 20 & 100 \\
\hline $\begin{array}{c}\text { Akhir } \\
\text { (Post) }\end{array}$ & 30 & 2820 & 94 & 90 & 100 \\
\hline
\end{tabular}

Berdasarkan tabel diatas, maka dapat disimpulkan bahwa terjadi peningkatan pemahaman peserta pengabdian terhadap materi sejarah lokal masa Revolusi Fisik. Terlihat pada tabel bahwa skor rata-rata pada saat pre-test adalah 44,67 dan skor rata-rata pada saat post-test adalah 94. Angka tersebut menunjukkan selisih sebesar 49,33 yang berarti terdapat peningkatan pemahaman terhadap sejarah lokal masa Revolusi Fisik setelah dilakukannya kegiatan pengabdian. Kegiatan ini ditutup pada hari Selasa, tanggal 17 November 2020 setelah dilakukannya evaluasi dan diskusi terhadap produk berupa materi ajar yang telah dibuat oleh peserta kegiatan dalam tugas mandiri yang diberikan pada hari ketiga.

\section{Penutup}

Sejarah perjuangan rakyat Musi Rawas pada masa Revolusi Fisik tahun 1947-1949 merupakan salah satu bagian dari sejarah lokal yang terdapat di Provinsi Sumatera Selatan, tepatnya di Kabupaten Musi Rawas. Materi ini dapat diajarkan pada peserta didik dalam berbagai media pembelajaran, salah satunya podcast sejarah atau (podse). Membuat media pembelajaran merupakan salah satu kompetensi yang harus dimiliki oleh guru di era sekarang. Selain untuk meningkatkan kualitas pembelajaran, media pembelajaran juga dapat menunjang penilaian portofolio para guru.

Setelah melaksanakan pendampingan materi untuk guru sejarah se-Kota Lubuklinggau, diperoleh informasi bahwa para guru sejarah yang tergabung dalam MGMP Sejarah yang mengikuti pendampingan ini memiliki pengetahuan baru mengenai sejarah lokal di Musi rawas secara umum dan Lubuklinggau secara khusus. Para guru sejarah nantinya dapat mengemas materi sejarah lokal di daerahnya dengan berbagai media pembelajaran untuk kemudian digunakan dalam proses pembelajaran di kelas. Pada dasarnya, penggunaan media pembelajaran, apapun bentuknya, dapat mempermudah peserta didik dalam menyerap materi ajar yang diberikan oleh guru dalam aktivitas kegiatan belajar mengajar di sekolah. 
Secara keseluruhan kegiatan pendampingan materi ini berjalan dengan lancar. Tim pengabdian optimis bahwa guru sejarah di Lubuklinggau dan sekitarnya memiliki banyak peluang untuk membuat media pembelajaran yang baik dan efektif untuk menunjang proses pembelajaran. Dalam hal ini, guru dapat membuat berbagai media pembelajaran berbasis teknologi yang bertemakan sejarah lokal/kearifan lokal, lalu menyesuaikannya dengan kurikulum yang berlaku. Keunikan sejarah lokal sendiri menjadi sebuah keniscayaan, karena setiap daerah memiliki karakteristik lokalitas yang berbedabeda untuk dikembangkan.

\section{Daftar Pustaka}

Abd. R, H. (2014). Pembelajaran Sejarah. Ombak.

Abdullah, T. (1985). Di Sekitar Sejarah Lokal di Indonesia. Dalam Taufik Abdullah (ed). Sejarah Lokal di Indonesia. Gadjah Mada University Press.

Akbar, S. (2013). Instrumen Perangkat Pembelajaran. PT Remaja Rosdakarya.

Hariyono, H. (2017). Sejarah Lokal: Mengenal yang Dekat, Memperluas Wawasan. Sejarah Dan Budaya. Jurnal Sejarah, Budaya, dan Pengajarannya, 11(2), 160_ 166. https://doi.org/10.17977/um020v11i22017p160

Hasan, S. H. (2015). Pendidikan Sejarah, Kemana dan Bagaimana? Makalah dipresentasikan di Seminar Asosiasi Guru Sejarah.

Kartodirdjo, S. (1992). Pendekatan Ilmu Sosial dalam Metodologi Sejarah. Gramedia Pustaka Utama.

Kochar, S. K. (2008). Teaching of History. Gramedia Widiasarana.

Komalasari, K. (2018). The Influence of Living V alues Education-Based Civic Education Textbook on Students' Character Formation. International Journal of Instruction 11, 1 (2018), 395-410.

Levesque, S. (2010). On Historical Literacy: Learning to Think Like Historian. Journal for Social Research 3, 2 (2010), 42-46.

Marta, N. (2020). Penelitian Tindakan Kelas sebagai Upaya Peningkatan Profesionalisme Guru Sejarah Di Sekolah Menengah Atas Kabupaten Bogor. 17(1), 22-29.

Pahlevi, M. R., \& Hudaidah. (2020). Tindakan Kelas Bagi Guru Sejarah Sekolah Menengah Atas Di Palembang. Jurnal Praksis dan Dedikasi Universitas Negeri Malang, 3(1), 34-38.

Saripudin, D., Yulifar, L., \& Anggraini, D. N. (2021). Pelatihan Pembuatan dan Pemanfaatan Replika Sejarah dan Peta E-Pen Bagi Guru-Guru SMA/MA. ABDI: Jurnal Pengabdian dan Pemberdayaan Masyarakat, 3 (1) Juni.

Sayono, J. (2013). Pembelajaran Sejarah Di Sekolah: Dari Pragmatis Ke Idealis. Jurnal Sejarah Dan Budaya, 7(1), 9-17. http://journal.unnes.ac.id/sju/index.php/ijhe\%0APENGARUH

Suryadi, A. (2013). Guru-Guru Sejarah Sma Di Kota Semarang Dalam Kemampuan Pemanfaatan Media Google Earth Dalam Pembelajaran. Jurnal Penerapan Teknologi Dan Pembelajaran, 11(2), 95-104.

Widja, I. G. (1989). Sejarah Lokal Suatu Prespektif dalam Pengajaran Sejarah. 
Departemen Pendidikan dan Kebudayaan.

Wineburg, S. (2000). Making Historical Sense" In Knowing, Teaching, and Learning History: National and International Perspectives, edited by Peter N. Stearns, Peter Seixas and Sam Wineburg 306-25. New York University Press.

Wiyanarti, E., Supriatna, N., \& Winarti, M. (2020). Pengembangan Sejarah Lokal Sebagai Sumber Pembelajaran Sejarah Yang Kontekstual. FACTUM: Jurnal Sejarah Dan Pendidikan Sejarah, 9(1), 67-74. https://doi.org/10.17509/ factum.v9i1.21666

Yusuf, S., Asmi, A. R., \& Pahlevi, M. R. (2020). Perjuangan Rakyat Musi Rawas pada masa Revolusi Fisik 1947-1949. Program Studi Pendidikan Sejarah FKIP Universitas Sriwijaya.

Zia, Ulhaq et al. (2017). Pembelajaran Sejarah Berbasis Kurikulum 2013 di SMA Kotamadya Jakarta Timur. Jurnal Pendidikan Sejarah 6, 2 (2017), 1-12.

Zahro, M., Sumardi, \& Marjono. (2017). The Implementation Of The Character Education In History Teaching. Jurnal Historica, 1(2252), 1-11. 
30 | Manhaj: Jurnal Penelitian dan Pengabdian Masyarakat | Vol. 10 No. 1, 2021

Halaman ini sengaja dikosongkan 